To Maega $\mid$ Jurnal Pengabdian Masyarakat

Oktober 2021, Vol. 4, No.3, hal. 263-271

$\operatorname{ISSN}(P): 2622-6332 ; \operatorname{ISSN}(E): 2622-6340$

http://www.ojs.unanda.ac.id/index.php/tomaega

\title{
Tingkat Pemahaman Ibu Pada Perawatan gigi anak Pada Komunitas Kelompok Mom and Me RS Islam Surabaya
}

\author{
Evy Afiyah Syagran ${ }^{1}$, Budhi Setianto ${ }^{1 *}$, Agus Aan Adriansyah ${ }^{1}$, Akas Yekti \\ Pulih Asih ${ }^{1}$, Difran Nobel Bistara ${ }^{1}$, Nikmatus Sa'adah ${ }^{2}$ \\ ${ }^{1}$ Universitas Nahdlatul Ulama Surabaya, 60237, East Java, Indonesia. \\ ${ }^{2}$ Institut Ilmu Kesehatan Bhakti Wiyata Kediri. \\ E-mail Correspondent: Budhisetianto@yahoo.com \\ Article History: \\ Received: 19-08-2021; Received in Revised: 10-09-2021; Accepted: 21-09-2021 \\ DOI: http://dx.doi.org/10.35914/tomaega.v4i3.818
}

\begin{abstract}
Abstrak
Berdasarkan data Riskesdas 2018, menunjukan 93\% anak usia dini mengalami gigi berlubang. Beberapa penelitian menujukkan pentingnya pemahaman orang tua terhadap pengetahuan tentang perawatan gigi pada anak. Pengabdian masyaakat ini (1) Membuat leaflet terkait perawatan gigi anak sebagai bahan edukasi kepada masyarakat, (2) Menyelenggarakan kuliah Whatsup Grup (WAG) tentang perawatan gigi anak, (3) Membuat video edukasi terkait perawatan gigi anak sebagai bahan edukasi kepada masyarakat, (4) Melakukan edukasi melalui Youtube Chanel tentang perawatan gigi anak.dari pelaksanaan dapat disimpulkan Leaflet yang sudah dibuat sangat memberikan manfaat kepada semua pengunjung poli gigi RS Islam Surabaya meningkatkan pengetahuan para ibu untuk pentingnya menjaga kesehatan gigi anak. Kuliah WAG yang diadakan mampu meningkatkan pengetahuan ibu dan ayah peserta dengan kenaikan pengetahuan sebesar 23,71\%. Bagi ayah / ibu yang belum berkesempatan mengikuti kuliah WAG bisa berkesempatan untuk melihat youtube chanel RS Islam Surabaya dengan tema tingkat pemahaman ibu terhadap pemahaman perawatan kesehatan gigi anak.
\end{abstract}

Kata Kunci: Kesehatan gigi anak, Whatsup Grup, Leaflet, Youtube Chanel

\begin{abstract}
Based on data from Riskesdas 93\% of early childhood experience cavities. Several studies have shown the importance of parental understanding of knowledge about dental care in children. This community service (1) makes leaflets related to children's dental care as educational materials for the community, (2) organizes Whatsup Group (WAG) lectures on children's dental care, (3) makes educational videos related to children's dental care as educational materials for the community, (4) Conducting education through the Youtube Chanel about children's dental care. From the implementation, it can be concluded that the leaflets that have been made are very beneficial to all visitors to the dental clinic of the Surabaya Islamic Hospital, increasing the knowledge of mothers about the importance of maintaining children's dental health. The WAG lectures that were held were able to increase the knowledge of the participants' mothers and fathers with an increase in knowledge of $23.71 \%$. For fathers/mothers who have not had the opportunity to attend WAG lectures, you can have the opportunity to watch the YouTube channel of the Surabaya Islamic Hospital with the theme of the level of mother's understanding of the understanding of children's dental health care.
\end{abstract}

Key Word: Children's dental health, Whatsup Group, Leaflet, Youtube Chanel 


\section{Pendahuluan}

Anak merupakan warisan terbesar dari sebuah keluarga yang harus dijaga dan dirawat dengan baik (Kemenkes, 2002). Menurut undang undang kesehatan definisi anak adalah sampai batasan umur 18 tahun.sedangkan WHO mendifinisikan anak adalah dari usia didalam kandungan sampai dengan 19 tahun (Soediono, 2014). Anak memiliki hak untuk dijaga dan di berikan kecukupan gizi sehingga terhindar dari kekurangan gizi, dan dijaga dari sakit, salah satunya adalah sakit gigi pada anak.

Gigi adalah salah satu organ tubuh yang memiliki fungsi untuk mengunyah makanan dan membantu agar manusia dapat berbicara dengan jelas. Organ tubuh ini terbuat dari terbuat dari protein dan mineral, serta kalsium (Senjaya, 2016), masalah yang sering dihadapi dalam merawat gigi anak adalah penyakit karies gigi. Karies adalah penyakit yang terjadi pada jaringan keras gigi , yaitu sementum , email dan dentin dikarenakan adanya jasad renik yang terdapat dalam karbohidrat yang diragikan. Proses ini diawali dengan kejadian demineralisasi pada jaringan keras gigi, diikuti dengan rusaknya bahan organiknya (Fatimatuzzahro dkk, 2016). Berdasarkan data Riskesdas 2018 menunjukkan 93\% anak usia dini mengalami gigi berlubang pada usia 5 - 6 tahun (Riskesdas, 2018). Pentingya peran orang tua dalam membantu anak untuk perawatan gigi sehingga tidak terjadi kejadian sakit gigi sangat dibutuhkan (Gayatri, 2017). Penelitian yang dilakukan oktariana(2017) menunjukan bahwa rendahnya pengetahuan ibu yang dilakukan bersama dengan anaknya menunjukkan korelasi signifikan terhadap status kesehatan gigi dan mulut anaknya (Oktarina dkk., 2017)

Beberapa permasalahan gigi pada anak yang sering terjadi(Maharani \& Rahardjo, 2013) adalah (1) Sariawan, (2) Gigis, (3) Tanggalnya gigi susu, (4)Gigi Tumbuh, (5) Radang Gusi, (6) Gigi tidak rata. Dari berbagai masalah gigi dan mulut yang sering dialami anak-anak. Peran orang tua sangat besar dalam memastikan kesehatan gigi dan mulut anak di masa perkembangannya(Razi dkk., 2020). Orang tua memberikan peranan penting dari permasalahan gigi yang di alami oleh anak anak, perlunya pemahaman terkait edukasi dari berbagai sumber literasi dalam tema terkait kesehatan gigi anak (Mulyati \& Amita, 2013).

Dari berbagai permaslahan yang dihadapi tentang pentingnya pemahaman orang tua terhadap perawatan gigi anak diharapkan pemgabdian masuarakat yang dilaksanakan ini mampu memberikan kontribusi dalam menyelesaikan masalah tersebut. Tujuan dari pengabdian masyarakat ini adalah (1) Membuat leaflet terkait perawatan gigi anak sebagai bahan edukasi kepada masyarakat, (2) Menyelenggarakan kuliah Whatsup Grup (WAG) tentang perawatan gigi anak, (3) Membuat video edukasi terkait perawatan gigi anak sebagai bahan edukasi kepada masyarakat, (4) Melakukan edukasi melalui Youtube Chanel tentang perawatan gigi anak. 


\section{Metode}

Menindak lanjuti tujuan dari pengabdian masyarakat berikut adalah pelaksanaan pengabsian masyarakat yang akan di selenggarakan. Kegiatan pengabdian masyarakat ini menggunakan 3 metode yaitu (1) Pembuatan Leaflet, (2) Kelas Online dengan menggunakan WAG (Whatsup Grup) (3) Menggunakan Video Edukasi yang nantinya akan di upload di Youtube Chanel. Berikut adalah metode yang digunakan

\subsection{Pembuatan Leaflet}

a. Alat / Bahan: Kertas Film A4, Desai Grafis, Percetakan

b. Sasaran: semua pengunjung rumah sakit

c. Manfaat: memeberikan edukasi kepada masyarakat melalui leaflet sehingga mampu meningkatkan pengetahuan kepada masyarakat terkait kesehatan pada gigi anak.

\subsection{Kelas Online dengan Menggunakan WAG (Whatsup Group)}

a. Alat / Bahan: Komunitas WAG, Zoom Platform

b. Sasaran : Peserta yang mendaftar dan bersedia masuk dalam komunitas mom and me RS Islam Surabaya

c. Manfaat : memeberikan edukasi kepada masyarakat melalui kuliah online WAG sehingga mampu meningkatkan pengetahuan kepada masyarakat terkait kesehatan pada gigi anak.

\subsection{Video Edukasi dan Youtube Chanel}

a. Alat / Bahan: Kamera, Peraga, Production House, Youtube Chanel Platform

b. Sasaran: pengunjung Youtube Chanel RS Islam Surabaya

c. Manfaat : Memberikan edukasi kepada masyarakat melalui kuliah online WAG sehingga mampu meningkatkan pengetahuan kepada masyarakat terkait kesehatan pada gigi anak

\subsection{Evaluasi Kegiatan}

Beberapa program yang di buat akan berhasil dengan beberapa indicator hasil sebagai bahan hasil adalah sebagai berikut

\subsubsection{Leaflet}

Pembuatan leaflet yang nantinya akan di gunakan untuk memberikan edukasi kepada setiap pengunjung pasien di poli gigi RS Islam Surabaya.

2.4.2 Kelas Online Whatsup Grup

Kelas online dalam media Whatsup Grup sebagai bahan evaluasi keberhasilan adanya suatu komunitas dalam bentuk grup whats up sebagai wadah pembelajaran

\subsubsection{Video Edukasi dan Youtube Chanel}

Pembuatan video edukasi tentang perawatan gigi pada anak yang nantinya akan di di buat sebagai edukasi di media youtube chanel sehingga bisa digunakan sebagai bahan media online 


\section{Hasil dan Pembahasan}

\subsection{Leaflet}

Leaflet adalah media cetak yang berupa selembar kertas yang dicetak dengan menggunakan gambar yang menarik sehingga audience tertarik untuk membaca dan belajar dari apa yang disampaikan pesan melalui leaflet tersebut(Razi et al., 2020). Sampai sekarang leaflet masih banyak digunakan dikarenakan kesederhanaan metode dan informasi yang diberikan cukup efektif dan efisien (Nubatonis, 2017). Metode leaflet dapat dipelajari dengan mandiri dan berulang sehingga mampu meningkatkan pengetahuan tentang suatu ninformasi (Meliyanti, 2015).
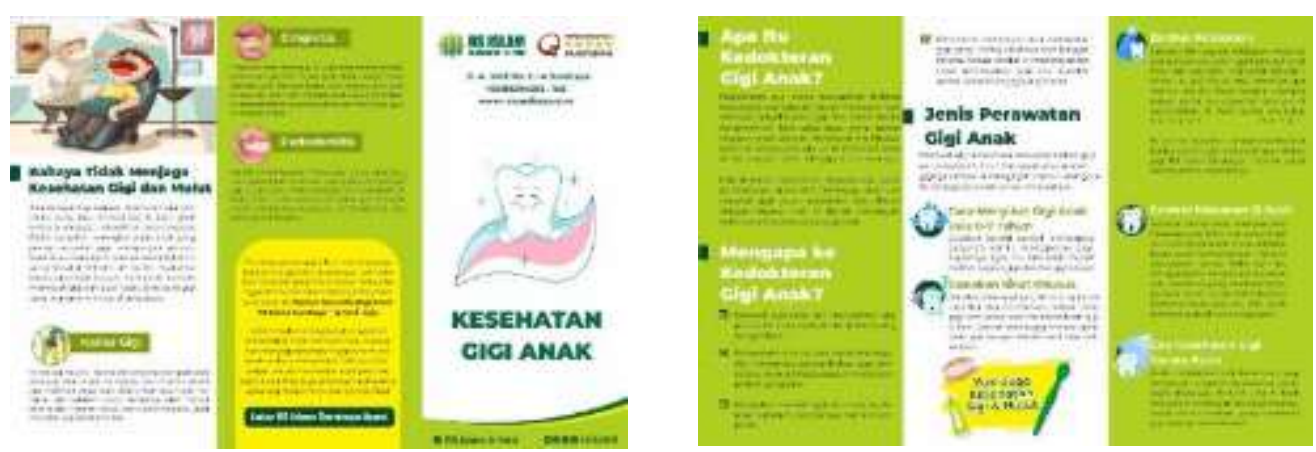

Gambar 1. Pembuatan Leaflet Kesehatan Gigi Anak

\subsection{Kelas Online dengan menggunakan WAG (Whatsup Grup)}

Suatu bentuk pembelajaran baru adalah dengan mengunakan media social yaitu whatsup grup. Pembuatan grup ditujukan untuk mempermudah pelaksanaan kuliah online, mempermudah apabila ada pertanyaan dari peserta sehingga pemteri bisa langsung memberikan jawaban (Fakhriyah et al., 2021). Diawali dengan memberikan pengumuman untuk mengajak peserta mengikuti kuliah whatsup grup. Peserta mendaftaran diri dengan menggunakan google form. Apabila setuju peserta akan dimasukkan dalam grup diskusi (Putriyani, 2021). Pelaksanaan diaali dengan membuat grup diskusi dan perkenalan antar anggota. Pemaparan video edukasi diputar dalam whatsup grup, setelah selesai pemaparan dilakukan diskusi dan melakukan tanya jawab dengan seluruh peserta(Anandita, 2020) 

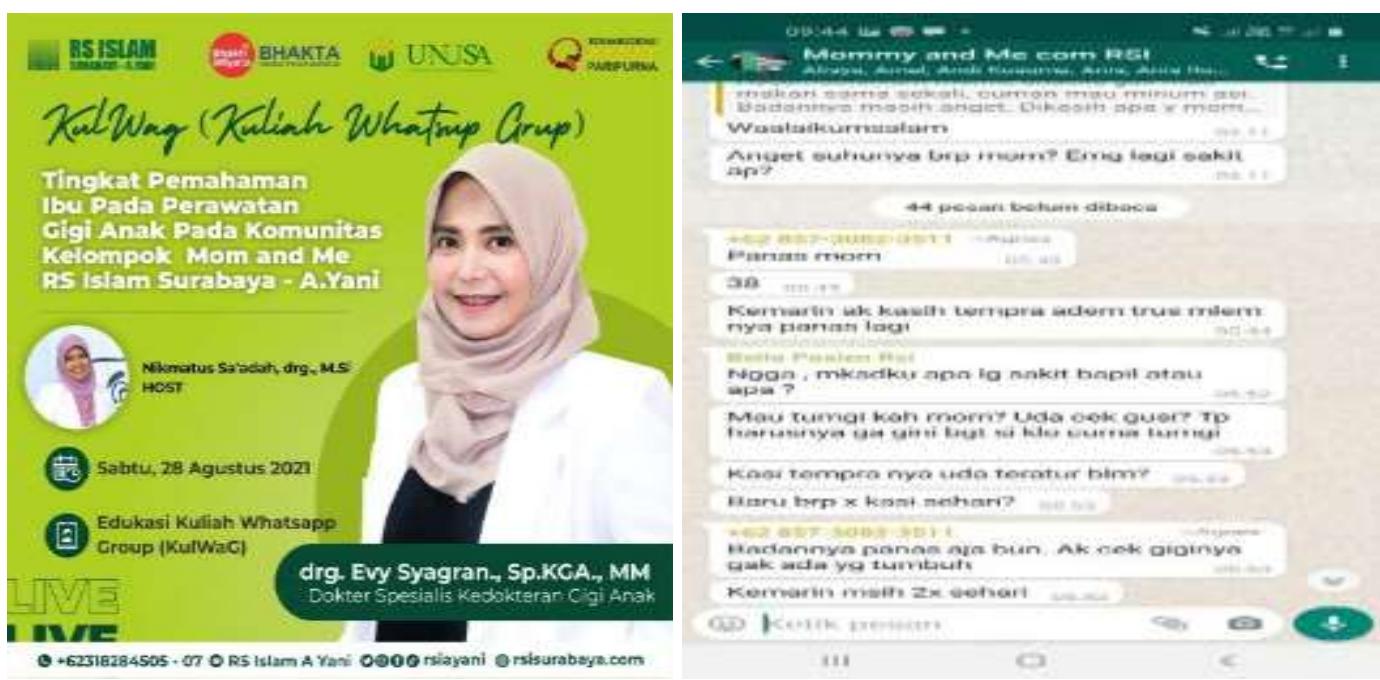

Gambar 2. Leaflet Promosi Kul WAG dan Komunitas WAG mommy an me RS Islam Surabaya dengan tema Kesehatan Gigi Anak Group

Berikut adalah demografi peserta yang mengikuti kuliah online Whatsup

Tabel 1. Demografi Peserta Yang Mengikuti Kuliah Online Whatsup Group

\begin{tabular}{clcr}
\hline No & Keterangan & Jumlah & Prosentase \\
\hline 1 & Karyawan RS Islam Surabaya & 51 & $33,3 \%$ \\
2 & Umum & 102 & $66,7 \%$ \\
& & & \\
No & Usia & Jumlah & Prosentase \\
1 & $<25$ Tahun & 15 & $9,8 \%$ \\
2 & $25-30$ Tahun & 77 & $50,3 \%$ \\
3 & 30 - 35 Tahun & 34 & $22,2 \%$ \\
4 & 35 - 40 Tahun & 13 & $8,5 \%$ \\
5 & 40 Tahun & 14 & $9,2 \%$ \\
& & & \\
No & Status & Jumlah & Prosentase \\
1 & ASN & 10 & $6,5 \%$ \\
2 & Karyawan Swasta & 94 & $61,4 \%$ \\
3 & Mengurus Rumah Tangga & 46 & $30,1 \%$ \\
4 & Usaha Sendiri & 3 & $2,0 \%$ \\
& & & \\
& Row Labels & Jumlah Anak \\
1 & 1 Anak & 90 & $58,8 \%$ \\
2 & 2 Anak & 33 & $21,6 \%$ \\
3 & 3 Anak & 22 & $14,4 \%$ \\
4 & Lebih Dari 3 Anak & 8 & $5,2 \%$ \\
\hline & Grand Total & 153 & $100,0 \%$ \\
\hline
\end{tabular}

Berdasarkan Tabel 1 memberikan informasi kuliah WAG ini diikuti 153 peserta. Selanjutnya peserta diberikan pretest dan post test dengan menjawab beberapa 
pernyataan dari panitia dengan menjawab 10 pernyataan berikut adalah hasil pre test dan post peserta.

Tabel 2. Hasil Pre dan Post Test kuliah Online Whatsup Grup

\begin{tabular}{clcc}
\hline No & Pernyataan & Pretest & Post Test \\
\hline 1 & Pengetahuan perawatan gigi sejak dini & $65,50 \%$ & $85,70 \%$ \\
& Bahaya apabila tidak melakukan & & \\
2 & perawatan gigi & $63,40 \%$ & $89,90 \%$ \\
3 & Pengenalan teething & $45,20 \%$ & $91,20 \%$ \\
& Pengenalan masa pertumbuhan gigi & & \\
4 & susu & $67,50 \%$ & $87,20 \%$ \\
5 & Arti dari caries & $52,80 \%$ & $98,40 \%$ \\
6 & Mengenal perawatan gigi pada anak & $76,30 \%$ & $92,90 \%$ \\
7 & Gosok gigi dengan cara yang benar & $81,20 \%$ & $91,50 \%$ \\
8 & Pengecekan kesehatan gigi secara benar & $76,80 \%$ & $92,60 \%$ \\
& Jenis makana yang mengganggu & & \\
9 & kesehatan gigi & $75,40 \%$ & $91,80 \%$ \\
10 & Alasan kenapa harus ke dokter gigi & $78,20 \%$ & $98,20 \%$ \\
\hline & & $68,23 \%$ & $91,94 \%$ \\
\hline
\end{tabular}

Tabel 2 memeberikan informasi terjadinya peningkatan yang signfikan dari pre test dan post test sebesar $23,71 \%$

\subsection{Menggunakan Video Edukasi}

Pandemi diawali pada Maret 2020, hal ini menyebabkan terjadinya pergeseran dari segala aktifitas offline menjadi aktifitas online, salah satu kegiatan adalah video edukasi kepada masyarakat (Ramadisu dkk, 2020). Pembuatan video edukasi sangatlah penting digunakan untuk metode pembelajaran, secara visual dalam bentuk gambar yang bergerak mempermudah orang untuk lebih memahami media pembelajaran (Imany dkk., 2019) (Didiharyono \& Qur'ani, 2019). Harapan dari pembuatan video edukasi ini nanti akan digunakan sebagai sara edukasi di media social dan kuliah whatsup group (Azzahra, 2017). Video edukasi merupakan hal yang sering kita jumpai, metode ini sangat cukup efektif dan efisien sebagai metode pembelajaran (Agustini, 2020) (Ariyanti et al., 2020).

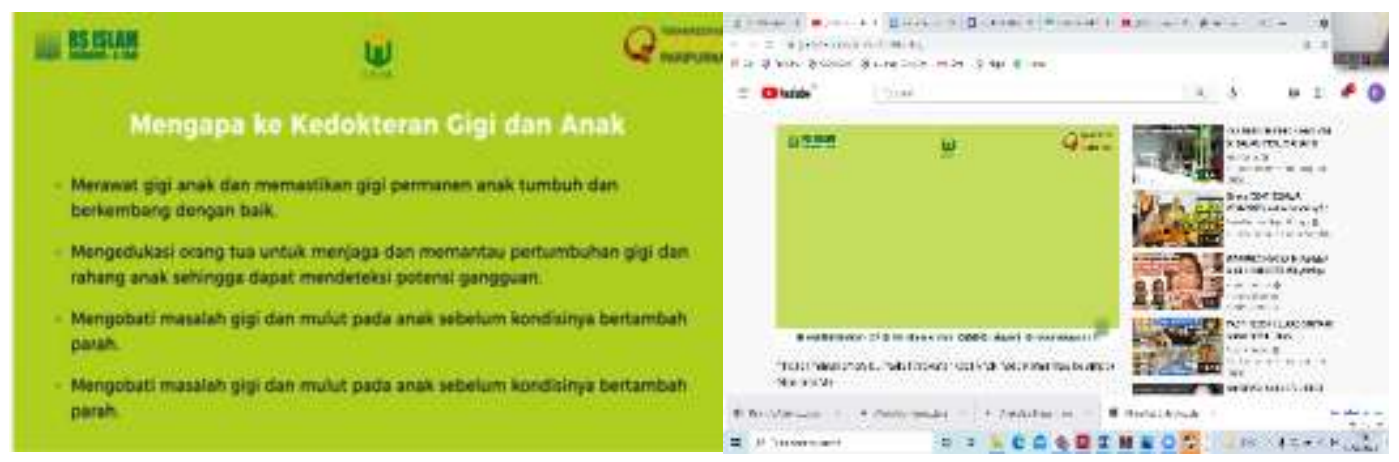

Gambar 3. Video Edukasi Terkait Kesehatan Gigi Anak dan Edukasi yang dilakukan Pada Youtube Chanel 
[ 269 ] Evy Afiyah Syagran, dkk / To Maega : Jurnal Pengabdian Masyarakat, Vol.4; No.3; Oktober 2021

\subsection{Edukasi Melalui Youtube Chanel}

Penggunaan media youtube merupakan bukan hal yang asing bagi setiap orang, pembelajaran ini dinilai sangat menyenangkan dan sangat efektif (Ma'usara, 2020), karena pengguna youtube sudah sangat banyak (Habibie, 2020). Harapan dengan di uploadnya youtube chanel semakin banyak orang yang akan melihat dan mempelajari lebih lanjut tentang kesehatan gigi (Yuniati dkk., 2021).

\section{Kesimpulan}

Leaflet yang sudah dibuat sangat memberikan manfaat kepada semua pengunjung poli gigi RS Islam Surabaya meningkatkan pengetahuan para ibu untuk pentingnya menjaga kesehatan gigi anak. Kuliah WAG yang diadakan mampu meningkatkan pengetahuan ibu dan ayah peserta dengan kenaikan pengetahuan sebesar 23,71\%. Bagi ayah / ibu yang belum berkesempatan mengikuti kuliah WAG bisa berkesempatan untuk melihat youtube chanel RS Islam Surabaya dengan tema tingkat pemahaman ibu terhadap pemahaman perawatan kesehatan gigi anak.

\section{Ucapan Terimakasih}

Terimakasih kepada LPPM UNUSA yang memfasilitasi kegiatan Pengabdian Masyarakat ini, kelompok WAG mom and me RS Islam Surabaya, RS Islam Surabaya. Yang telah mendukung dan memberikan support sehingga pengmas ini dapat berjalan dengan baik.

\section{Daftar Pustaka}

Agustini, K., \& Ngarti, J. G. (2020). Pengembangan Video Pembelajaran Untuk Meningkatkan Motivasi Belajar Siswa Menggunakan Model R \& D. Jurnal Ilmiah Pendidikan Dan Pembelajaran, 4(April 2020), 62-78.

Anandita, M. Y. R. (2020). Penyuluhan Kesehatan Melalui Telemedia Pada Ibu Hamil tentang Mempersiapkan Pemberian ASI Eksklusif (Health Education through Telemedia for Pregnant Women about Preparing for Exclusive Breastfeeding). Jurnal Pengabdian Masyarakat Bakti Parahita, 01(01), 5665 .

Apriani Ramadisu; Oktaviani, Wiwin A, Y. M. (2020). Pembuatan Video Metode Tangkap Layar Sebagai Media Pembelajaran Daring Di Masa Pandemi Covid-19. JMM (Jurnal Masyarakat Mandiri), Vol 4, No 6 (2020): DESEMBER, 1049-1057.

Ariyanti, R., Preharsini, I. A., \& Sipolio, B. W. (2020). Edukasi Kesehatan Dalam Upaya Pencegahan dan Pengendalian Penyakit Hipertensi Pada Lansia. To Maega: Jurnal Pengabdian Masyarakat, 3(2), 74. https://doi.org/10.35914/tomaega.v3i2.369

Azzahra, R. (2017). Analisis Pembuatan Video Media Pembelajaran dalam Mata Kuliah Pembelajaran Menyimak 0leh Mahasiswa Kelas A Semester V Prodi Pendidikan Bahasa Indonesia Universitas Khairun Ternate. Widyabastra, 05(1), 8-14. 
Didiharyono, D., \& Qur'ani, B. (2019). Increasing Community Knowledge Through the Literacy Movement. To Maega: Jurnal Pengabdian Masyarakat, 2(1), 1724. https://doi.org/10.35914/tomaega.v2i1.235

Fakhriyah, F., Athiyya, N., Jubaidah, J., \& Fitriani, L. (2021). Penyuluhan Hipertensi Melalui Whatsapp Group Sebagai Upaya Pengendalian Hipertensi. SELAPARANG Jurnal Pengabdian Masyarakat Berkemajuan, 4(2), 435. https://doi.org/10.31764/jpmb.v4i2.4479

Gayatri, R. W. (2017). Hubungan Tingkat Pengetahuan Dengan Perilaku Pemeliharaan Kesehatan Gigi Anak Sdn Kauman 2 Malang. Journal of Health Education, 2(2), 201-210. https://doi.org/10.15294/jhe.v2i2.22612

Habibie, A. (2020). Youtube Chanel Sebagai Media Pembelajaran Bahasa Inggris Mandiri di Era Industri 4.0 (p. 153).

Imany, S., Artanti, G. D., \& Kandriasari, A. (2019). Pengembangan Media Video Pembelajaran Pembuatan Chiffon Cake Pada Mata Kuliah Kue Kontinental. Media Pendidikan, Gizi, Dan Kuliner, 8(2), 63-66. https://doi.org/10.17509/boga.v8i2.21966

Kemenkes. (2002). UNDANG-UNDANG REPUBLIK INDONESIA NOMOR 23 TAHUN 2002 TENTANG PERLINDUNGAN ANA.

Ma'usara, S. (2020). PENGGUNAAN MEDIA YOUTUBE PADA PEMBELAJARAN MENULIS TEKS ULASAN SISWA KELAS VIII MTS NEGERI 13 JAKARTA TAHUN PELAJARAN 2019 / 2020 Skripsi Diajukan kepada Fakultas Ilmu Tarbiyah dan Keguruan untuk Memenuhi Salah Satu Syarat Mencapai Gelar Sarjana Pendidika.

Maharani, D. A., \& Rahardjo, A. (2013). Mothers' Dental Health Behaviors and Mother-Child's Dental Caries Experiences: Study of a Suburb Area in Indonesia. Makara Journal of Health Research, 16(2), 72-76. https://doi.org/10.7454/msk.v16i2.1632

Meliyanti, F. (2015). Efektivitas Penggunaan Leaflet Terhadap Peningkatan Pengetahuan Remaja Kelas VIII Tentang HIV / AIDS Di SMP Negeri 2 Ogan Komering Ulu. Jurnal Akademika Baiturrahim, 4(2), 26-34.

Mulyati, S., \& Amita, N. (2013). Praktek merawat gigi pada anak. 2(2), 130-135.

Nadie Fatimatuzzahro, Rendra Chriestedy Prasetya, W. A. (2016). Bangsalsari yaitu 5 . Indeks gigi yang karies ( D ) lebih dominan yaitu sekitar $67 \%$ dibanding gigi yang telah dicabut ( $\mathrm{M}$ ) sebanyak $2 \%$ dan gigi yang telah ditambal ( F) hanya $1 \%$. Masih tinggi nya gigi yang karies ( D ) dibandingkan gigi yang sudah di. Jurnal IKESMA, 12, 84-90.

Nubatonis, M. O. (2017). Promosi Kesehatan Gigi dengan Menggunakan Media Leaflet Terhadap Pengetahuan, Sikap dan Status Kebersihan Gigi dan Mulut Siswa Sekolah Dasar Kota Kupang. Jurnal Info Kesehatan, 15(2), 451-468.

Oktarina, O., Tumaji, T., \& Roosihermiatie, B. (2017). Korelasi Faktor Ibu Dengan Status Kesehatan Gigi Dan Mulut Anak Taman Kanak-Kanak Di Kelurahan Kemayoran Kecamatan Krembangan, Kota Surabaya. Buletin Penelitian Sistem Kesehatan, 19(4), 226-235. https://doi.org/10.22435/hsr.v19i4.6815.227-235

Putriyani, S. (2021). Pekatihan pembelajaran daring menggunakan aplikasi 
[ 271 ] Evy Afiyah Syagran, dkk / To Maega : Jurnal Pengabdian Masyarakat, Vol.4; No.3; Oktober 2021

whatsapp bagi guru SMP. Maspun Journal of Community Empowerment, 3(1), 49-53.

Razi, P., Surayah, \& Widia. (2020). Promosi Kesehatan Dengan Pola Asah, Asih Dan Asuh Dalam Meningkatkan Kemandirian Menyikat Gigi Pada Anak Usia Dini Di Tk Khalifah 2 Jambi Tahun 2019. Ramanujan Journal, 1(2), 7-12.

Riskesdas. (2018). Laporan_Nasional_RKD2018_FINAL.pdf. In Badan Penelitian dan Pengembangan Kesehatan (p. 198).

Senjaya, A. A. (2016). Gigi lansia. Jurnal Skala Husada, 13(1), 72-80.

Soediono, B. (2014). Info Datin Kemenkes RI Kondisi Pencapaian Program Kesehatan Anak Indonesia. Journal of Chemical Information and Modeling, $53,160$.

Yuniati, I., Suyuthi, H., \& Hakim, M. (2021). Pelatihan Pemanfaatan Media Youtube Dalam Pembelajaran Bahasa Indonesia Di Sma It Kota Bengkulu. Jurnal Pendidikan Dan Pengabdian Masyarakat, 4(1), 38-47. 